\title{
Historical and typological approaches to Mauritanian and West Saharan Arabic
}

\author{
CATHERINE TAINE-CHEIKH
}

Mauritania, like most countries in the Sahel-Saharan region, forms a transitional area between North and sub-Saharan Africa, in terms of climate, ecosystem, and inhabitants.

The traditional lifestyle of the desert inhabitants, which continued well into the twentieth century, has not yet entirely disappeared, despite an accelerating trend towards sedentarization over the past few decades. In some ways, it is reminiscent of the lifestyle of the bedouin of the Arabian Peninsula. However, the West African Sahara has long been the homeland of Berber speakers. As far as Niger and, to a large extent, Mali, are concerned, it has remained so, but in the westernmost part of the Sahara, the situation changed radically over the course of the second millennium AD.

Very little is known about the conditions under which Berber speakers switched to Arabic, and almost nothing about the linguistic practices current in the area in past centuries. Nonetheless, based on the linguistic study of the so-called Hassanniyya Arabic dialect spoken in the Western Sahara, certain elements of the linguistic history of the region can be suggested. To do this, we will compare the data with data from other Arabic dialects as well as the Berber variety (Zenāga) which used to be spoken in Mauritania, but which is virtually extinct today. Moreover, these comparisons will, where possible, take into account the historical, anthropological, and social contexts which can shed light on them. Certainly, a wide range of factors contributed to making Hassāniyya what it is today. The Western Sahara, given its peripheral position, was, for several centuries, very isolated from the rest of the Arab world.

The first part of this study will be devoted to the Banī Hassān, ${ }^{1}$ considered to be the original speakers of Hassāniyya. We will examine their history and origins, and various characteristic elements of their language. The second part will treat the situation in the

\footnotetext{
1 The form Banī is used in reference to its dialectal pronunciation; the equivalent in CLA is Banū.
} 
Western Sahara before and after the arrival of the Banī Hassān, the various phases of Arabization, and the effects of contact with Arabic on the non-Arab populations. We will explore some of the language's original features, including its unitary nature, and the conditions which gave rise to its creation.

\subsection{ORIGIN(S) AND THE ARAB LEGACY}

The language which is most widely known as Hassāniyya (or, in Morocco, Hassāni) is

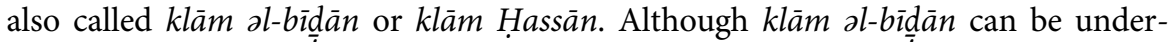
stood, in a Mauritanian context, as meaning 'language of the Moors', ${ }^{2}$ the label klàm Hassān (even more than Hassāniyya and Hassāni) makes reference to a specific group, the Banī/Awlād Ḥassān, and to their ancestor Hassān, considered the father of the language.

Because this group played a very important role in forming and shaping society in the Western Sahara, specialists in Moorish history and genealogy have paid them a great deal of attention, but very little is known about these regions before their arrival. Here, for example, are the brief comments with which the work by Mokhtar Ould Hamidoun on the Hassān tribes begins: ' The Banū Hassān are the sons of Hassān b. Mukhtār b. Muhammad b. Ma'qil, ancestor of the Ma'qil Arabs who came from Hijāz and Najd to the Maghreb with the Hilāīs in the fifth century AH [= eleventh c. AD]. They settled near the Muluya until they received a call for help from ${ }^{\mathrm{c}} \mathrm{Ali}$ b. Yiddir, who was leader of Sūs following the Almohad period. They moved closer to him and dominated the Sūs, levying tribute from its inhabitants following wars with these $b$. Yiddir. They then rebelled against the Marinids, and the [Marinid] sultan Yussuf b. $\mathrm{Ya}^{\mathrm{c}}$ qub attacked them in 668 ah [ $\left.=\mathrm{AD} 1269\right]$ with a force of 12,000 horsemen. He vanquished them, and that was the reason for the penetration of some of their group into Mauritania, which they reached at the beginning of the eighth century AH [ = end of the fourteenth century AD]'. This terse introduction nonetheless provides some avenues which I will now explore in more detail: the $\mathrm{Ma}^{\mathrm{c}} \mathrm{qil}$ Arabs, their migration with the Hilālīs from the eleventh century on, and their Hijāzi and Najdi origins.

\subsubsection{THE MA ${ }^{9}$ QIL ARABS}

As far as this group is concerned, most authors refer to the writings of Ibn Khaldūn. ${ }^{4}$ This is the case, for example, with Shaykh Muhammad al-Imām ibn al Shaykh Mā̄al 'Aynin, the Moorish author quoted by Norris in The Arab Conquest of the Western Sahara. Here is the passage on the original location of the Banū Ma'qil in Norris's

\footnotetext{
2 The expression literally means 'language of the whites', but in Mauritania, it is commonly used for all Arabic speakers who speak Hassāniyya (see Taine-Cheikh 1989).

${ }^{3}$ Mokhtar Ould Hamidoun devoted much of his life to documenting the tribes of Mauritania, but most of the works appearing under his name (e.g. Ibn Hāmidūn 1990) were published posthumously.

4 Thus all mentions of the name of Ma'kil, in Cuoq's collection of Arab sources (1975), refer to pages in the works of Ibn Khaldūn.
} 
translation: 'Ibn Khaldūn has remarked-he being alive in the eighth/fifteenth century-that in his time the Banū $\mathrm{Ma}^{\mathrm{c}}$ qil were among the most amply provided of the nomad Arabian tribes. Their homeland lay in the deserts of the furthest Maghrib. They were the neighbours of the Banū ' ${ }^{\circ} \overline{m i r}$ ibn Zughbah (Hilālīs) in their tribal haunts to the south of Tilimsān and they extended as far as the Atlantic. They had three clans (buțūn), Dhū 'Ubaydallāh, Dhū Manșūr and Dhū Hassān. The first of these was neighbour to the Banū ${ }^{\complement} \bar{A}$ mir and their district lay between Tāwarìrt and the Tall and all the district lying to the south. The second group extended from Tāwarìrt to the Dar`ah and to the Tall which faced it, whilst the third (Hassān) were in the territory between the Wādī Dar' ah and the Atlantic. Their Shaykhs dwelt in the region of Nūl (the Wād Nūn), the capital of the Sūs. They were the overlords of the furthest Sūs and they pastured in the sandy regions as far as the terrain of the mulattamūn - that is, the Gudālah, Massūfah, and Lamtūnah' (Norris 1986: 19-20).

Although, at that time, the Banī Hassān appear to have made up a specific group located farther south than the others, and despite the fact that seven centuries have passed since the era Ibn Khaldūn wrote about, one would expect there might be closely related features shared by Hassāniyya and the dialects which can be linked to the presence of the Banī Ma'qil. Indeed, all the work on Moroccan Arabic shows that there are several types of dialect in the country, and that there is a set of features which quite clearly distinguishes the group of 'pre-Hilālì' from the 'post-Hilālì' Arabic dialects. This distinction originates in Marçais 1961, where all bedouins who entered North Africa in the eleventh century are more or less described as Hilālīs.

In the case of Morocco, the distinction between 'Hilālīs' and 'Ma' qilīs' can be fuzzy, but the dialects of the second type are often classified among the specific group of 'Ma'qili' dialects which cover the western Maghreb and extend widely into Algeria, notably in the district of Oran. ${ }^{5}$

Colin (1986) describes the 'bedouin' dialects as 'dialects of the plains': 'the Atlantic plain, from Arzila to Mogador (modern Essaouira), with extensions into the interior, the Moulouya basin, eastern Moroccan plateau and the Moroccan Sahara region (Oued Ghïr, Oued Zīz, etc.)'. Noting that little is known about them, and that they differ from one another, in all likelihood, in the greater or lesser extent of their conservatism, he characterizes them globally as sharing the following features:

- voiced realization $[\mathrm{g}]$ of the $q \bar{a} f ;$

- retention of the interdentals;

- a short-vowel system with minimal oppositions (lacking $i$ ), characterized by the insertion of an ultra-short transition vowel with a $u$ colouring following $k$, $g$, $h$, and $\dot{g}$ (as in kǔbār 'big', iǧ̌u ed 'he sits', and rŭgw $\bar{g} g$ 'thin') and certain doubled consonants: $b b, f f, m m, k k, g g, q q$, and $x x$ (as in lugrubb $b^{w} a$ 'the crows', $n u f f^{w} \bar{a} x a$ 'bellows', and sukkw $\bar{a} r$ 'sugar');

\footnotetext{
5 The study by Marçais (1908) on the dialect of the Saïda Ülād Bṛāhīm gives a good example of this type of dialect, which Cantineau (1940) labelled the 'D' dialects'.
} 
- resyllabication owing to stress being maintained on the first syllable (yakkatbu 'they write', baggarti 'my cow');

- a 3 msng pron suffix in -ah;

- a genitive particle translating 'of', $n t \overline{a^{\varphi}}$, or $t \bar{a}^{\varphi}$ (derived from CLA mat $\bar{a}^{\varphi}$ ) which agrees in gender and number with its antecedent noun;

- reduction of the diphthong in the pl inflection of defective verbs ( $g l \bar{u} /$ yeglü 'fry', $n s \bar{u}$-yensī 'forget');

- a few specific lexemes such as $b \bar{a} / i b \bar{\imath}$ 'want', yāməs 'yesterday', $\underline{d} a r w ə k, \underline{d} u r k$ 'now' (cf. CLA $\underline{d} \bar{a} l$-waqt).

Over the past decades, the pioneering work of Loubignac (1952) on the Zaër, and of Destaing (1937) on the Arabic spoken by the Sūs Chleuhs has been revisited (Aguadé 1998; Moscoso 1999) and complemented by other studies on dialects which have a voiced reflex $([\mathrm{g}])$ of the $q \bar{a} f$. Several of these (e.g. dialects spoken in Casablanca, Essaouira, Marrakesh, Settat) are urban, often strongly influenced by pre-Hilālī dialects (Aguadé 2013), but even in the Skūra oasis (Aguadé and Elyaacoubi 1995) and in the Valley of the Draa Oued (Venero 1997), the interdentals have disappeared. Of all the Moroccan dialects, that spoken by the Zaër is thus alone, alongside Hassāniyya, in having retained them.

Other features listed by Colin, while not completely general, are very widespread, such as the existence of two short vowels $\partial$ and $\breve{u}$; but none of these features is found in Hassāniyya, with the exception of two temporal adverbs ( $y \bar{a} m \partial s$ 'yesterday' and dark 'now'). ${ }^{6}$ Among other 'Moroccan' characteristics absent in Hassāniyya, one finds: the passive-reflexive in $t t$ - or $t$-; the use of a preverbal particle before the p-stem verb ( $k \bar{a}$ - and especially $t \bar{a}-)$; generalization of the form in - $t i$ for both genders in the 2 sng in the s-stem verb; presence of a post-verbal negative element $-\check{s}$. All of these features have been regularly noted in Moroccan dialects which have $g<\mathrm{OA} / q /$, despite a few exceptions: thus the Skūra dialect, which has retained the distinction in gender and a few traces of the passive in $n$-, as in Hassāniyya. ${ }^{7}$

Of all the Ma'qilì dialects, it is the Zaër 'bedouin' dialect that Hassāniyya appears to be closest to because of its retention of the interdentals, but also because of convergences observed in the lexical domain (Taine-Cheikh 1988-98). However, there are many features in the Zaër dialect that are not shared by Hassāniyya, e.g.

- the shift of the CLA affricate $\check{g}$ to $d$ in contact with $\check{s}, s$ or $z$ (' $d \bar{u} z a$ 'old lady', dəh̆s 'donkey foal'); ${ }^{8}$

- lengthening of the short vowel in open syllables before a suffix ( ${ }^{9} \partial r f a t+u>$ 'arfātu 'she recognized him');

${ }^{6}$ The short vowel system in Hassāniyya, with neutralization of the $i / u$ distinction, is typically that of the Maghreb 'bedouin' dialects (Cohen 1970).

${ }^{7}$ However, in Hassāniyya the prefix $n$-is restricted to the passive of the basic form, and is generally combined with a dental stop (ttan- or ttnə-) in Sküra, where it is used only for the passive-reflexive of the derived verb patterns (Aguadé 1994).

${ }^{8}$ The shift $\check{g}>d$ is found in Hassāniyya in a few lexemes based on three radicals (cf. däšṛa 'city'; ddäššä 'burp'; dșar/dșar 'be over familiar, be audacious'). The first two show shifts which happened long ago. The third, apparently more specific to Morocco, may have been borrowed. 
- paradigm of the verbs 'eat' and 'take' (kla, yākǔl, and $x d a$ yāxǔd);

- the interrogatives $f \bar{e}^{-y} n$ 'where?', $m n \bar{e}^{-y} n$ 'from where?', and škūn 'who?'.

On all of these points, Hassāniyya shows divergent forms:

- ' $z \bar{u} z$ 'old woman' (with $z-z$ and without the f ending);

- 'arvat $+u>^{\top}$ 'ar'vtu'she knew him';

- kāl, yäwkäl 'eat', and xād, yäwxad 'pass through, go along';'

- mnäyn 'where?', man mnäyn 'from where?', and man 'who?'.

It is unsurprising that Heath (2002) pays particular attention to 'Saharan Arabic'10 in his comprehensive comparative work on Moroccan dialects. Of the lexemes specific to 'Saharan Arabic', I would pick out the following: $g \underline{d} \partial v$ 'vomit' (alongside tbowwa'); haggiyyä 'hiccough'; $u^{\varsigma} a$ 'wake up'; 'addäl and wāsä 'do'; ra 'find' (alongside žbar); mrag 'exit, go out'; nzəl and näggäz 'go down'; rașșav 'jump'; șabb 'pour'; läwwäd 'search for'; 'albä 'nape'; bähňššä 'throat'; däbbūs 'wooden stick'; maznä 'cloud'; kadyä 'mountain'; shāb 'rain'. ${ }^{11}$ Given that all of these terms are part of the basic vocabulary, this list confirms the fact that Hassāniyya preserves many original features, and invites us to look at dialects other than the $\mathrm{Ma}^{\mathrm{C}} \mathrm{qili}$ dialects of Morocco in order to find similarities.

\subsubsection{A SOJOURN IN THE MAGHREB WHICH LASTED SEVERAL CENTURIES}

In the 1940s, linguistic investigations carried out by Jean Cantineau across the various regions of Algeria made it possible to establish several dialect groups, among both 'sedentary' and more or less recently Arabized populations, and bedouin of Arabian origin (or who had been Arabized after the arrival of the Hilālis). Because of their central position in the Maghreb, some dialects spoken in Algeria belong to groups which extend over both sides of the border. I have already mentioned the case of what Cantineau called the 'D' dialects, spoken both in western Algeria and in Morocco. One finds a comparable situation in the east of the country, where Cantineau's group 'E' dialects spread well into Tunisia, and even beyond. Lastly, still among the 'bedouin' dialects (the majority dialects in Algeria), there are the dialects, spoken by the major nomadic groups of the south, which Cantineau dubbed the ' $A$ ' dialects. Other studies then specified the limits of various linguistic features, such as that of the forms yensu and tensi as compared to yensāw and tensāy (Grand'Henry 1976: 49), thereby redefining the contours of the various groups and giving rise to mixed dialects. This is the case, for example, of the Arabic dialect spoken in Saoura, which Grand'Henry (1979: 227) presents as a 'DA' dialect, i.e. 'a 'D'

\footnotetext{
9 One notes, in contrast, that in both cases the interdental final root-consonant is emphatic $(d>d)$.

10 This label is applied essentially to Hassāniyya, to which the dialects of some oases in the south are more or less closely related.

11 Among the examples excluded are terms found in the oases of the south but not in Hassāniyya.
} 
dialect presenting not only the characteristics of Moroccan and Mauritanian dialects, but also slightly influenced by the 'A' dialects of the central Sahara.

The dialect spoken in the oases of the south-western Algerian Sahara (Béchar, Abadla, Igli, Beni Abbes) is in effect closely related to those spoken in the southeastern Moroccan oases (including the loss of interdental consonants). However, with the exception of the preposition ' $a$ an and the p-stem inflection of the něktbu type which indeed shows the same syllable structure as in Hassāniyya (contrary to bgărtěk 'your cow' and nḍ̆rběk 'I hit you' which in Mauritania would take the forms bäg r rtäk and nad $\left.{ }^{2} r b a ̈ k\right)$, convergence with Hassāniyya remains quite limited, despite the coexistence of the passive in both $n$ - and $t$ -

The differences between Hassāniyya and the 'A' dialects seem too clear-cut, at least on two points (the passive in $t$ - and metatheses of the type žězzār $>z \check{e} z \check{z} \check{a} a$ ! 'plug a gap' and $\check{z} e b s>z e b s$ ' plaster'), for one to think, as suggested by Cantineau (1940: 228) that the territory of the 'A' dialects extended all the way into Mauritania. However, beyond retention of interdentals, diphthongs, and the prefix $a$ - with pattern IV verbs in $a f^{\varsigma} a l$, there are several other important shared features: firstly the imāla of the long $\bar{a}$ in final position (although much weaker than in eastern Maghreb) and secondly the form of the syllable structure when a vowel-initial suffix is added (compare kät ${ }^{e} l t o$ 'she killed him', yed ${ }^{e} r s u$ 'they are threshing the wheat', and bäg ${ }^{o} r t i$ 'my cow' to the Hassāniyya forms provided).

There are three relatively detailed descriptions of the following dialects: that of the 'Arbā' (Dhina 1938), of Bou-Saada (Marçais 1945) and, further to the south, of the Mzāb region (Grand'Henry 1976) which did not retain the interdentals (probably owing to influence from Berber speakers' pronunciation). Other features shared with Hassāniyya are:

- the pattern II verbal noun in $t^{\varsigma} f^{\varsigma} \bar{a}$ rather than $t e f^{\varsigma} \bar{\imath} l ;^{12}$

- the variant $m f a^{\varsigma \varsigma} l \ddot{a}$ as pl of the pattern I participle mäf ${ }^{\varsigma} \bar{u} l\left(l_{-}{ }^{2} k b \bar{a} \check{s} m s a ̈ l l x a\right.$, pl of al-kəbš mäslūx 'the ram is skinned', Marçais 1945: 82); ${ }^{13}$

- pronominal forms expanded with the suffix - $y \ddot{a}$ as in the 2 fsng ntīyä/ntiyyä;

- two short vowels ( $a$ versus $i \sim u / \partial$ ) which formally distinguish between the s-stem and the imperative of geminated CaCC verbs as in hass 'he smelled' versus hiss/hoss 'smell!'. ${ }^{14}$

The regular shift from $\dot{g}$ to $q$ is another feature of the 'A' dialects which they share with Hassāniyya, but only some speakers (those originating from the areas located to

12 In Hassāniyya, the form täf $\varsigma^{\varsigma} \bar{l}$ is reserved for borrowings from CLA. Compare tahdād 'act of sharpening' with (note the $q$ characteristic of borrowings) tahqi q 'act of verifying'.

${ }^{13}$ However, this variant does not appear to be restricted to the A dialects and Hassāniyya. It has also been noted in the dialects of the Ülād Brāhīm and the Gabès El-Hamma.

${ }^{14}$ In contrast, the 2 sng gender distinction (following a consonant) which, in Hassāniyya, is based on the same vowel distinction ( $-\ddot{a} k$ vs. $-\partial k$ ), is not found in these dialects. Globally speaking, as far as gender distinction in pronouns is concerned, the more conservative Hassāniyya is closer to the Maghreb dialects situated further to the east. 
the east of a line extending from the north-east of Mauritania to the south-east). ${ }^{15}$ I will come back to this typically 'bedouin' feature (linked to the $g$ pronunciation of the $q \bar{a} f)$, which may be historically significant, even though these Maghreb dialects are not alone in possessing the feature (Cantineau 1936).

If one postulates that loss of the passive pattern in $n$ - and its replacement by patterns bearing the prefix $t$-/tt- (including pattern I) only recently became widespread in the ' $A$ ' dialects (or after the fourteenth century, at least), ${ }^{16}$ it is conceivable that Hassāniyya was, before that date, very similar to the dialects of the main nomadic tribes in Algeria.

It remains, however, to be explained why, instead of metathesis between sibilants and fricatives, characteristic of the 'A' (and 'D') dialects, Hassāniyya tends to show, as in eastern Maghreb dialects, assimilation of fricatives to sibilants, whatever their order within the root. Examples: (CLA Arabic) sarž 'saddle' and žazza 'shear' > (Hassāniyya) särz and zäzz; and > (south Tunisian dialect of the Marāzīg, after Boris 1958) $s^{a} r a z$ and $z e z^{z}{ }^{17}$

This is all the more troubling as Hassāniyya has many traits in common with various Libyan and Tunisian dialects (among others, the expression of the passive and the number of gender oppositions in verbal inflections), but also differs on several points from the two groups of 'bedouin' dialects identified by Marçais (1950). First, it shares neither the defective verb forms mšet and tensu (in Hassāniyya: $m \check{s} \bar{a} t$ and tänsāw), nor the lengthening of the 3 fsng ending before suffix (sallmātu 'she abandoned him'). Secondly, it differs from the central Tunisian 'H' group (Hilālī) in its passive form, as one might have expected, but also differs from the ' $\mathrm{S}$ ' (Sulaymī) group in the form $-a(h)$ taken by the 3 msng pronoun suffix in these dialects.

Therefore, once again, one may suppose that some of these features spread after the Banì Hassān had left the Maghreb. One can also hypothesize that the various groups (the Ma' ${ }^{\mathrm{C}}$ qilìs, Sulaymīs, and Hilālīs) arrived with relatively distinct dialects, of which today's dialects have retained traces: e.g. pronunciation of the 3 msng pronoun affix as $-a h$ or $-u{ }^{18}$ Personally, I believe that no hypothesis should be excluded, including one positing - at least for the Banī Hassān in particular and probably more broadly for the Banī $\mathrm{Ma}^{\mathrm{c}}$ qil-koineization phenomena during which variation was

15 Cohen 1963: 36-7 indicates the reverse tendency $(q>\dot{g})$ in south-west Mauritania, among the least educated-a tendency which is manifested in a few words such as $\dot{g} \check{s} \bar{a} b \ddot{a}$ 'type of tunic' and gandìr 'candle' (< qandīl), probably borrowed from 'sedentary' dialect speakers (cf. qəššāba and qandīl, Colin 1993: 1571, 1614). It is interesting to observe that this tendency is also noted in the Sūs and Essauoira for a few words containing both $q$ and $r$ (Moscoso 1999: 27; 2002: 38), but one must further note that, once again, this tendency is also found in the eastern Arab World.

16 According to Grand'Henry 1976: 5, the domain of these prestigious dialects, spoken by nomadic tribes who generally kept away from Berber-speaking areas, spread 'at the time of Turkish domination over Algeria (from the sixteenth to the nineteenth century): at that time displacement of rural and bedouin groups happened very frequently'.

17 The studies by Pereira (2010: 66-8) and Benkato (2014: 70) confirm the earlier sources on which my article on Libya was based (Taine-Cheikh 1984).

18 This distinction separates, for example, the dialects of northern Najd from those of the centre (Ingham 1982: 31). 
reduced, with the retained features often, although not always, being the most neutral or least novel.

As we saw, the Banī Ma ${ }^{\mathrm{C}}$ il were very numerous in Morocco, but this was not the case when they arrived in Egypt in the eleventh century (Norris 1986: 12): 'Drawing attention to the fact that the $\mathrm{Ma}^{\mathrm{c}} \mathrm{qil}$ entered the Maghrib with the Banū Hilāl, he [Ibn Khaldūn] emphasizes that their number comprised only a few extended families; less than a couple of hundred souls, hardly more. It was only after their settlement in the remotest part of the Maghreb that they became of any significance.' Ibn Khaldūn further specifies that they 'were confronted' with the Banū Sulaym; they had long 'been close' to the Banū Hilāl and 'settled' on their territory.

During their sojourn in the Maghreb between the eleventh and fourteenth centuries, the Banī $\mathrm{Ma}^{\mathrm{c}}$ qil thus had many relations with the other bedouin groups. Their dialect was profoundly modified in consequence, not only through contact with the other Hilāli and Sulaymì dialects, but also under the more or less indirect influence of 'sedentary' dialect speakers. Beyond the inventory of differences between dialects linked to the two waves of Arabization, there are in fact a certain number of characteristics shared by all of the Maghreb dialects. The generalization of $n$ - in the first person (sng and pl) of the p-stem, the near total absence of the ending - $n$ on the plural of p-stem verb forms (Taine-Cheikh 2014a), as well as the derived verb pattern $f^{\varsigma} \bar{a} l$ (as seen in byād 'turn white, blanch') are undoubtedly among the most remarkable of the morphological features. The lexicon provides further examples, such as the use of $g d a m$ (instead of $k a^{\varsigma}(a) b$ or 'argüb) for 'heel', hiut (instead of samak) for 'fish', 'atrūs 'billy-goat', fakrūn 'tortoise', dašra 'village, town', and žznwi 'knife' (WAD I: $174-5,269-70,337-8,377-8$; WAD II: 34,128$).{ }^{19}$

One must further note the dominant trend, in the Maghreb, towards the loss of short vowels in open syllables. ${ }^{20}$ This indicates above all that contact between speakers of Arabic and those of Berber, which must have been extensive at the time, must not be forgotten. ${ }^{21}$ Before coming back to the question of the Berber substrate however, I would like to discuss the presumed origins of the Banī $\mathrm{Ma}^{\mathrm{c}} \mathrm{qil}$.

\subsubsection{ANCIENT ORIGINS}

As to the origin of the Bani $\mathrm{Ma}^{\mathrm{c}} \mathrm{qil}$, all agree that they come from the Arabian Peninsula, but two opposing theses are espoused by genealogists, as indicated by Ibn Khaldūn (Norris 1986: 12-13): 'As for the lineages among the mass of men these are wholly hidden and quite unknown. The genealogists who are amongst the Arabs of

19 The difficulty is not finding examples of lexemes typically used in the Maghreb, or having a meaning specific to the Maghreb, but finding examples valid for the entire Maghreb, and for nowhere else. If one takes, for example, the case of akhal 'black' as an alternative to aswad, one realizes that this is a particularity of the western Maghreb, and that it is less common in the east of Algeria and in Tunisia (Taine-Cheikh 1989: 104, n. 8).

${ }^{20}$ Hassāniyya shows no trace of this in the form of an ultra-short vowel. On this point, it was more reductionist than the dialects spoken in the eastern Maghreb, and even the Algerian 'A' dialects.

${ }^{21}$ Berber also provided Maghreb Arabic with part of its shared lexicon (as is the case, e.g., of fakrūn and žวnwi). 
the Banū Hilāl count them among the Hilāli clans. But this is not so. They allege that their lineage comes within the household of the Prophet, going back to Ja' ${ }^{\mathrm{f}}$ far ibn Abi Țālib. Now that claim is likewise false. It is false because the offspring of Abū Tâalib and the Hāshimites were not desert folk who wander in search of pasture. The sound explanation is that they are Arabs of the Yemen. Among the Yemenite Arabs there are two specific clans. Each one of them is called Ma'qil.'

Ibn Khaldūn adds that, out of these two lineages, the more probable is that of Hārit ibn $\mathrm{Ka}^{\mathrm{c}} \mathrm{b}$, who descends from Madhij through Rabīªh. What is interesting in this detail is that it links this group to the uprising of the Bahraini Carmathians. The defeat of this movement, which Madelung (1978: 690) situates in AH 470/AD 1077-8, is said to be the reason for the arrival of the $\mathrm{Ma}^{\mathrm{C}} \mathrm{qil}$ in Upper Egypt, following the departure of some of the group from the Arabian Peninsula.

Moorish genealogists, who make no mention of relations with the Carmathians, instead prefer the prestigious reference to $\mathrm{Ja}^{\mathrm{c}} \mathrm{far}$, cousin of the Prophet-who died in AH 9/ad 631 at the battle of $\mathrm{Mu}^{\top}$ ta-which is to say, to Hijāzī and Najdī origins. This is not linked to any particular linguistic considerations, but, for Mokhtar Ould Hamidoun, it explains the names of the points of the compass in use in Mauritania, or at least among the Moors in the south-west. Indeed, if one considers the location of Medina, one observes, like him, that in relation to this city, the four terms take on all their meaning: täll (the mountain) is indeed to the north; šarg (the direction of the rising sun) is of course to the east, as it is everywhere; gablä (qibla) denotes the south, since Medina is to the north of Mecca; and lastly sāhal (the coast) signifies the direction of the sea, which is located to the west of Medina.

Although this hypothesis of a quasi-direct transposition of the geographical landmarks of a given place such as Medina does not solve the question of variation in the names of the cardinal points of the compass among the Moors (Brosset 1928; Taine-Cheikh 1991a), it does nonetheless explain quite simply the choice of the four terms, especially täll, which is not otherwise used by them. As for the use of gablä to refer to the south (and even the south-west or west in some regions of Mauritania), one must note that this is in no way exceptional in the Maghreb. ${ }^{22}$ This retention of the meaning 'in the direction of the south' can seem surprising at first, but perhaps it is less linked to the actual direction of the qibla in the original country than to the polysemy of the word qibla in CLA, which associates the direction of Mecca with the south. Whatever the answer, the problems raised by this polysemy have been resolved in Hassāniyya by distinguishing two separate roots: QBL for 'direction of Mecca' (= qiblä) and GBL for 'south' (= gablä) - an opposition which is also found in the verbs staqbäl and saqbäl, respectively 'take the direction of Mecca' and 'cause (s'one) to take the direction of Mecca' versus stägbäl and sägbäl 'take a southern direction' and 'cause (s'one) to take a southern direction'.

It is particularly with reference to these verbs with the prefix sa- that some linguists, following the thesis defended by Ibn Khaldūn, consider a direct connection between Hassāniyya and ancient Yemen to be proven. Thus Zavadovskij (1981: 11)

${ }^{22}$ Nor even in Chad or in the Sudan (WAD I: 441, map 149). 
considers that the retention of the South Arabic causative prefix $s$ - (for example, sahmar 'to make someone blush') is one of the 'Himyarisms' characteristic of the dialect. He does not appear to have been convinced by the arguments of Cohen 1963: 130-2 in favour of purely internal origins through the creation of a new causativefactitive pattern in parallel with the pattern X in st(ä)-. However, if there was external influence, it seems less plausible to consider that it is due to contact with South Arabia than that it is due to influence from Berber (a topic to which I will return).

The other evidence put forward by Zavadovskij is just as unconvincing. Concerning the prepositions ' $a n$ and ilä/ila (distinct from $\partial l$ 'to, for'), they are indeed productive in Hassāniyya (especially ${ }^{\top}$ an), whereas they have more or less completely disappeared from many Maghreb dialects, including that of the Saïda Ülād Brāhìm (Marçais 1908: 166-9). However, convergence with Middle Eastern dialects (where these prepositions are more productive) is far from total (Procházka 1993: 71-2, 139-63). ${ }^{23}$ Zavadovskij should instead have cited the example of qafa 'back' that Cohen (1963: 220) gives to denote 'behind' ( $v a$ gvä... 'behind the back of...') which Procházka (1993: 237) relates to various dialects spoken in the Arabian Peninsula and the Middle East-although Hassāniyya, like North Yemeni dialects (Behnstedt 1987b: 92), also shows spatial use of $u r \bar{a}$. In fact, in the domain of prepositions, the most interesting specificities of Hassāniyya are:

- sābag 'before', used only in this dialect;

- $k \bar{\imath}(f) / k \bar{e}(f)$ 'like', also characteristic of Upper Egypt and most Maghreb dialects;

- 'àgab 'after', of which one finds cognates both in some Maghreb 'bedouin' dialects (spoken by the Ûlād Brāhìm and Marāzīg) and those spoken in Mesopotamia and Arabia (in the Gulf, Ḍofār, Daținah, cf. Procházka 1993: 212).

Zavadovskij also mentions the pronunciation [q] for $\dot{g} a y n$ ( $b \dot{g} a>b q a$ 'he wanted') as another of the features of the South Arabian tribes. However, a particularity in pronunciation noted for Datinah shows the reverse tendency (Landberg 1901: 485; Cohen 1963: 37), also noted in central and southern Iraq (Rosenhouse 2006: 272). It is rather in various north Arabian dialects of the Middle Euphrates or Najd (Cantineau 1936: 39; Ingham 2008: 327), as well as in some spoken in the Gulf (Holes 2006b: 242; 2007a: 610; 2016: 53-4), that $\dot{g}$ tends to shift to $q$. Given the wide distribution of this feature in nomadic dialects, however, it is not certain that it constitutes a decisive element in the history of Hassāniyya.

In fact, there is no set of features that Hassāniyya shares with any particular group of eastern dialects. As for those noted, they do not belong to the most salient features serving to distinguish various groups of eastern 'bedouin' dialects. For example, Hassāniyya did not undergo the palatalization and affrication (whether conditioned or not) of $k$ and $g$, and nor does it have an affricated pronunciation of $\check{g}$, still less a switch to $y$. It is also unaffected by the effects of the so-called ghawa-syndrome, viz. the presence of a guttural consonant $\left(\mathrm{C}_{2}=x, \dot{g}, h,{ }^{\varsigma}, h\right)$ closing an initial syllable

${ }^{23}$ Furthermore, one must take into account the variant (i)läyn 'until, up until' (Taine-Cheikh 2014b: 16) which, in Morocco, is typical of Saharan dialects (Heath 2002: 498). 
whose vowel is $a$, , such that $\mathrm{C}_{1} \mathrm{aC}_{2}->\mathrm{C}_{1} \mathrm{C}_{2} \mathrm{a}-$ as in gahwa $>$ ghawa 'coffee' (Johnstone 1967: 6) or $\mathrm{C}_{1 a C}->\mathrm{C}_{2} \mathrm{CC}_{2} \mathrm{a}-$ as in gahawa (Blanc 1970: 125-7; de Jong 2007). In the morphological domain, there are no endings in $-n$, whether in verbal inflections or as an indefinite marker ('dialectal tanwin', see the chapters of Ferrando, Holes, Procházka, this volume).

What one does find, beyond various trends common to 'bedouin' dialects such as a tendency to emphatization and strong stress (Rosenhouse 1984: 10, 15), is rather a partial convergence, sometimes with one group of 'bedouin' dialects, sometimes with another. This is illustrated by the following comparisons, based on lexemes found in Hassāniyya (WAD I: maps 138, 41, 43):

- maznä 'cloud', not used in the Maghreb, but occurring widely in Arabian dialects;

- halmä (without a modifier) 'earlobe', not used in the Maghreb, but used in the Sudan, in Egypt, and in various other dialects, such as that of Irbid in Jordan;

- $\check{s} d \partial g$ 'cheek' (used less in the Maghreb than in the Chad-Sudan region) is found both in Sinai and in Hadramawt.

Lastly, I will mention two specific cases where lexical convergence extends into grammaticalization processes.

The first example (Taine-Cheikh 2013a) is that of $(a) r \bar{a}^{c} i$ which, in Hassāniyya, is used differently from (a)rā-. The latter form serves, as in many Maghreb dialects, to draw attention to an event, as in: (a)rāa-hu žä 'I inform (you) that he has come'. The first, by contrast, is a presentative (like Moroccan $h \bar{a}-)$ : $(a) r \bar{a}^{\mathrm{c}} \overline{\bar{l}}-h$ 'here he is'; $(a) r \bar{a}^{\mathrm{c}} \overline{\mathrm{i}}-h$ $\check{z} \bar{a} y$ ' here he comes'. Forms with the 'ayn, not used in the Maghreb outside Hassāniyya, have been noted in many eastern dialects, but it is the forms $\operatorname{ar}^{5} a / \operatorname{ar}^{\varsigma} i$, used in the dialects of Negev and north Sinai, to which the $(a) r \bar{a}^{c} i$ of Hassāniyya seems most closely related, both in their forms (for which the origin could be, rather than ${ }^{*} r a^{2} a$ 'see', $r a^{c} a$ 'keep, watch over') and in their use as (pure) presentatives. ${ }^{24}$

The second example (Taine-Cheikh 2011) concerns the two grammaticalized uses of $g \bar{a} m$ 'stand up' in Hassāniyya. The first, $g \bar{a} m$ followed by a verb in the p-stem or a participle, means 'begin to'. The second, gām always in the s-stem and coordinated using $u$ 'and' with another verb in the s-stem, takes on the meaning of 'then'. In the Maghreb, these inchoative and discoursal uses are found only, it seems, in Tunisia. In the Middle East, both uses are widespread, but the construction often becomes hypotaxic in both cases (Fischer 2002). Among the dialects having retained, at least partially, the use of the coordinator are those of Eastern Arabia (Holes 2001: 442) and those spoken in the Syrian High Jezireh (Bettini 2006). The latter dialect also has, as

\footnotetext{
${ }^{24}$ Henkin 2010: 134, 141 makes a clear distinction between the uses of 'presentatives of conversational discourse' ( $a r^{\text {r }}$ and hay) and 'evidential presentatives', susceptible of being used both in discourse and narratives. The latter forms, $t \underline{t} r \bar{a}(t)$, itrīt, based on the same root '-t- $r$ 'to transmit, pass on', also have a cognate in Hassāniyya: ätr $r$ u 'it seems that, it could be that'. This modal particle, in similar forms like atar, atarāt, tari and with a similar meaning, is common in the Mashreq (Iraq, Arabia, the Gulf) but rarely noted in the Maghreb, where it is used to denote known facts as in 'it is the case that..., indeed' among the Marāzīg (see Boris 1958: 4).
} 
in Hassāniyya, the verb 'take' (intransitively) to convey the meaning of 'then'. The only difference is that the Syrian verb shows metathesis ( $g i d a b$ ) which is absent from Hassāniyya ( $g b a d$ ), but this is enough to suggest that the hypothesis of parallel development is the most probable.

To conclude this comparison with eastern dialects, which also sheds new light on similarities with Tunisian dialects, one may say that there is convergence in plenty, especially with 'bedouin' dialects. However, the similarities do not make it possible to establish any precise genealogical link, even though Hassāniyya often appears to be most closely related to dialects having historical ties to Najdī Arabic. ${ }^{25}$

\subsection{A VERY GRADUAL ARABIZATION}

There is no direct ancient evidence of what the dialect of the Banī Hassān was like, but, in the absence of proof of any other distinct demographic inflow from Arabia, I will consider (as suggested by the label klām Hassān) that the dialect from which today's Hassāniyya springs was indeed that spoken by this branch of the Banī Ma' qil in southern Morocco. Even if this dialect showed major variations at the end of the fourteenth century - which is a possibility even though, in my view, not highly likely-it is clear that these were lost over the following centuries, given the dialectal unity found today.

Explaining this homogeneity will be one of the goals of this second section. It is one of the most surprising features of Hassāniyya, and it is further necessary to take into account the fact that, despite numerous conservative features, there are also many particularities which can only be innovations. Moreover, I shall note the effects of the substrate and adstrate: contact with non-Arabic languages over centuries has of course left traces, which contribute to the uniqueness of Hassāniyya. To do this, I will first turn to the Berber speakers who lived in the Western Sahara before the arrival of the Banī Hassān. Their language is now almost extinct, the end point of a process which began many centuries ago.

The switch from Berber to Arabic is the most salient aspect of a much more global process, Arabization. Anthropologists see this as a profound transformation within a given society, attended by changes to the kinship system, the founding myths, reorientation of genealogies and, more generally, the (re)writing of history. Some aspects of this 'comprehensive' Arabization happened long before the change in language, although the two are related. The first among them, as least from a chronological standpoint, concerns without doubt the Islamization of West Africa.

\footnotetext{
${ }^{25}$ As Holes (p.c.) has pointed out, various similarities exist between Hassāniyya and the Eastern Arabian dialects: not only the confusion of $q$ and $\dot{g}$ (and $\dot{g}$ and $q$ ) and the use of atar (see previous note) but also the neutralization of the $i / u$ opposition and the widespread use of the tif $^{\top} \bar{a} \bar{l}$ pattern II verbal noun (though such forms are now in recession in Eastern Arabia). I thank him for these details (which certain historical facts presented earlier may throw light on) and am very appreciative more generally of his very attentive reading of this chapter.
} 


\subsubsection{THE TAKRŪR BERBERS}

Before the arrival of Islam, the prehistory of this region can be divided into several phases, and the border between the nomadic world of oases and a sedentary lifestyle fluctuated depending on changing climatic conditions. ${ }^{26}$ For Vernet (1993: 304-7), a specialist in the prehistory of Mauritania, the settlement of the first Berbers in the Tagant was contemporaneous with the end of the agro-pastoral economy which gave rise, in the Neolithic era, to the amazing 'urban civilization of Tichitt'. The new arrivals left some traces: 'first, chariot engravings and (rare) copper mounts, tombs and superimposed dwelling structures in the villages, then "Libyco-Berber" and Tifinagh engravings'.

Vernet noted that the rock-painted chariots in the Western Sahara, which almost always (95\% of cases) had two wheels and generally (68\%) one drawbar, depicted a specific type: ox-drawn chariots designed to transport heavy produce (very common in the Sahara). More recently, Gauthier and Gauthier (2011) compared the incidence of chariot engravings and those of the Libyco-Berber inscriptions and noted that the boundaries of the areas where they are found coincided in the south and east with those of the Berbers. Then, comparing their distribution to that of the three alphabets (Pichler and Le Quellec 2009), they observe that while the chariots were shared by the Atlas and Saharan regions, the former was the domain of the 'classical' alphabet, whereas the latter corresponded both with the domain of the 'transitional' alphabet and to that of consistent types of construction: crescents, aligned monuments, and monuments topped with a ' $\mathrm{V}$ ' shaped structure. ${ }^{27}$

These ancient cultural differences within Berber-speaking societies coincide quite harmoniously with the distinction between the Berber dialects of the north and those of the south which I have observed on several occasions and which, in terms of the vowel system and retention of laryngeals, makes Zenāga similar not only to Tuareg, but also to Ghadamsi (Cohen and Taine-Cheikh 2000; Taine-Cheikh 2005).

Arab authors describe the populations inhabiting the desert space between the Maghreb and the western Bilād al-Sūdān at the end of the first millennium as 'Șanhāja' having no settled dwelling and drawing their sustenance from camels (they had no wheat or any other cereals). They are characterized by the fact that they 'veil their faces, following one of their customs [and] do not wear a tunic but drape themselves in swathes of cloth.' In the period described by Al-Ya'quibì (d. AH 278/AD 891), it was beyond this region (i.e. Waddān) and more to the east that the 'population is Muslim, entirely Ibạḍì' (Cuoq 1975: 48). In the west, the nerve centre was the town of Ghașt (i.e. Awdaghust, on the current site of Tegdaoust,

${ }^{26}$ This border 'seems to have been situated, in the last centuries of the first millennium of our era, in the vicinity of the eighteenth parallel, i.e. not far from Nouakchott for the coastal regions, at the southern limits of the western Aouker, to the southern bank of the Aouker from the Hodh more to the east; it may have been more to the north for all the plateaux of Tagant and Assaba.' (Robert-Chaleix 1986, quoted by Vernet 1993: 375).

${ }^{27}$ The domain of the 'archaic' alphabet (characterized by monuments of another type: Haouanet and dolmens) is located in the Maghreb and the Canary Islands. 
excavated by medievalist archaeologists). ${ }^{28}$ It is described as a 'prosperous oasis, with (fixed) dwellings', the king of which, very powerful, was 'without religion and without religious law'.

The town's prosperity, and more broadly that of Gajaaga (part of the Ghana 'Soninke' empire) began in the eighth century and was linked to the gold trade (Bathily 1989: 172): 'The wealth of the Ghana-Wagadu in gold stemmed from the role of intermediary played by the country in exchanges between the Sudan on the one hand, and the Sahara and Mediterranean countries on the other.' Gold was traded for various products and luxury articles (cloth, weapons) from the Mediterranean, and other goods from closer by, also highly precious, such as salt, the extraction of and trade in which appears to have been largely in the hands of the Saharans. ${ }^{29}$

Contact between nomadic Berber-speaking populations and those speaking a variety of Malinke (or Mandinka) was certainly very frequent at the time. It is even likely that the Azer language, ${ }^{30}$ which Monteil (1939) recorded from its last speakers in the ancient caravan cities of Mauritania, testifies to these contacts, in which it perhaps functioned as a 'trade language'. However that may be, Ibn Hawqal (d. AD 988/ AH 377) ${ }^{31}$ mentions the presence of Șanhāja in Awdaghust, alongside that of Berber tribes (such as the Șarța and Banū Massūfa) living in isolation between Sijilmāsa and Awdaghust, with no contact with urban life, but controlling the road (Cuoq 1975: 73-5).

This trade across the desert, considered since the Classical era as 'mute' because 'peaceful', as shown by Farias 1974, was not only economic in its effects. It was also an opportunity for Takrūr (the Western Sahara-Sahel zone) to experience more extended relations with merchants of various origins. In the centuries immediately following the Muslim conquest of North Africa, however, Islam does not appear to have penetrated far into the heartland. This situation only changed at the end of the eleventh century, with the emergence of the Almoravid (al-murābițūn) movement which launched a holy war against miscreants and bad Muslims. This movement had major consequences, as the Almoravids for a time dominated both Morocco and western Algeria, and conquered Andalusia.

Here I will briefly mention the question of the mulattamün (the 'veiled ones'), whose name clearly refers to the Șanhajja of the Western Sahara, without its being clear where the territories of the 'seventy tribes' of which (according to Ibn Abì Zar`) the Șanhāja were composed were actually situated.

There is controversy over where the Almoravid movement set out from. Some mention the island of Tidra, a toponym which derives from Zenāga $t \underline{i} \underline{d} r a^{2} n$ 'cemetery'.

${ }^{28}$ On the probable Berber origin of Awdaghust, see Galand 1970. On its Zenāga etymology and its relation with the Hassāniyya dialect name Tegdaoust, see Taine-Cheikh 2002: 451.

29 The three major salt pans in western Africa named by Cuoq (1975: 95, n. 3) - Taghāza in Mali, Idjī in southern Tïris, and Awlīl on the Atlantic coast (perhaps identical to Ntarart)-have Berber-sounding names. Idjil comes from Berber 'iron' $(z-[z]-l)$, awlïl comes from the Zenāga word meaning 'bottom (of s'thing'), and an-tärärt means 'a [place] with salt' (Taine-Cheikh 2008a: 612, 560, 447).

30 This is a Soninke dialect which has been lightly influenced by Zenāga.

31 He was perhaps the only Arabic chronicler to have visited the place. 
If one considers the origins of its first leaders (the Djudāla and Lamtūna tribes), the movement seems to have been born in the extreme south-west of Mauritania (perhaps near the Senegal River, whose name, in all probability, is derived from the same name, Zenāga). ${ }^{32}$ It then enrolled followers from well outside the Șanhāja Berber tribes, including from the blacks of Bilād al-Sūdān. What became of these tribes in the Sahara after the twelfth century is the subject of controversy.

The veil of the mulattamün, leaving only the eyes visible, of course suggests the Tuareg, who have retained this practice among the upper tiers of nobility through the centuries. For Hunwick (1970) and Norris (1975), who identified several groups among them whose names are comparable to those of the eleventh-century tribes (such as the Inussufen and the Massūfa), the Tuareg identity of the Lamtūni informant of al-Suyūtī (a famous Egyptian polymath of the fifteenth century) is beyond doubt. For Ould Cheikh (1995), who notes the presence, up to the present day, of a tribe bearing the name Lamtūna in the centre-south (Gorgol) of Mauritania, it could also have been a literate Walātian from east Mauritania, especially as stigmatization of the 'griot' (musician-courtier) caste was and is unknown among the Tuareg.

In fact, one may suppose that the separation into two main Șanhāja Berber groups must have happened quite early, at the beginning of the second millennium AD, if not before. Indeed, while Zenāga has long been considered as the western branch of Berber (Aikhenvald 1988), distinct from the other, southern branch constituted by Tuareg, features of this western Berber have been noted outside Mauritania. The discovery of Tetserrét, a minority Berber language spoken in Niger, and its greater similarity to Zenāga than to Tuareg (Attayoub 2001; Lux 2013) would tend to significantly increase the domain of western Berber. Furthermore, given that the Berber characteristics of several varieties of northern Songhai (Korandjé, Tadaksahak, Tagdal) seem also to belong to the western type (Souag 2010, 2015), it is possible that this variety of Berber still had a strong presence in the region in the fifteenth century, before the use of the language of the Songhai empire became widespread. The case of Tagdal is all the more interesting, as its name and that of the tribe which speaks it (Igdalen) both refer to the Djudāla/G(u)dāla of the Almoravid era. ${ }^{33}$

Although these groups speak languages with a very markedly mixed character, it appears that in certain highly literate tribes bilingualism is an obvious form of resistance, with the mother tongue remaining the prestige language, even if restricted to domestic use. From this viewpoint, the behaviour of the scholarly Ayttawari Seslem, speakers of Tetserrét who became bilingual following contact with the Tuareg (Walentowitz and Attayoub 2001), appears very similar to that of the last

32 According to Ibn $\mathrm{Abī} \mathrm{Zar}{ }^{\complement}$ (who died between $\mathrm{AD} 1310$ and 1320), '[the] Emir Yahyā b. Ibrāhīm of the Djudāla ruled after the death of Muhammad b. Tārsinā the Lamtūnī. The Djudāla and Lamtūna are brothers, descended from the same father; they live at the extremity of the countries of Islam, in the vicinity of the Sūdān, and, to the west, border the ocean.' (Cuoq 1975: 231).

${ }^{33}$ In the case of the Kel Aghlal Tuareg Tameseghlalt, the variety spoken by the aklän 'slaves', studied by Drouin (1984), may also contain features from western Berber. One should note that in Mauritania, Hassāniyya-speaking groups bear the names Gdālä and l-Aghlāl. As for the Massūfa, one sees in the Mäshdūf (especially well represented in the Walāta region) some at least of their descendants. 
speakers of Zenāga, who also belonged to literate tribes (Dubié 1940; Taine-Cheikh 1998). The history of relations between $z w a \bar{a} y \ddot{a}$ 'clerics or scholars (Fr. marabouts)' and hassān 'warriors' will shed some light on the question.

\subsubsection{GROUPS, STATUS, AND LANGUAGES}

Societies in the West African Sahara and the Sahel have many common features, in both the rigidity of their hierarchies and the type of distinctions made in them.

The first of the distinctions is within the nobility between warriors and scholars, found among both nomads and sedentaries, albeit with significant variation in terms of numbers and relative political and economic weight. Whereas the warriors seem to have had the upper hand politically among the Tuareg and Soninke (as well as numerically in the former), it is the literate group Tooro66e which appears to have had primacy among the Hal-Pulaaren, at least from the eighteenth century (Kane 2004: 289ff.). The bedouin society of the Western Sahara on the eve of French colonization was in the rather peculiar situation of the warriors having the upper hand politically, but the scholars being stronger in numbers.

There were exceptions to this dichotomy, given that certain Saharan tribes (e.g. the Kunta and l-Aghlāl in Mauritania, the Kel Antașār among the Tuareg) were literate, but also frequently waged wars. There is nonetheless an opposition between the two nobilities, that of letters and that of the sword, the genesis and importance of which, in the Western Sahara, were largely connected to the arrival of the Banī Hassān.

Far from being comparable to a 'swarm of locusts' destroying everything in its path (according to the description given by Ibn Khaldūn of the arrival of the Hilāīs in the Maghreb), the expansion of the Arabs southwards seems to have been gradual. Moreover, Arabic sources mention several successive waves of departure, that of the Awlād Rizg towards south-western Mauritania, which preceded that of the other descendants of Üday b. Hassān (the Awlād Dāwūd and the Maghāfira), whereas the descendants of the other sons of Hassān (the Brābīsh and the Awlād Dläym) set off in other directions, more eastward in the case of the Brābish. Thus it is virtually impossible to be precise about the locations of the various groups affiliated with the Banī Hassān. All factors indicate that the geographic positions of the various groups fluctuated, depending largely on power struggles, climatic circumstances, and other factors.

In the tenth century, Ibn Hawqal noted the might of the king of the Șanhāja and described various tribes, such as the Banū Massūfa, praising their courage, endurance, and sense of direction, and noting the tax they levied on trans-Saharan trade.

When, at the beginning of the sixteenth century, Valentim Fernandes described his sojourn on the coast of Africa, to the north of Senegal, he labelled all the inhabitants Mauros, but also made a distinction between 'Alarves' (= Arabs) and 'Azenègues' (= Zenāga). The former 'have neither kings, nor codes, nor ordinances' (obeying only their own rules-including those dictated by modesty and filial respect) and 'all consider themselves nobles' (de Cenival and Monod 1938: 93, 97). The 'Alarves' despise both the 'Azenègues' of the sea, called Shirmeyros in reference to 'fish' 
(Zenāga əššiymi where $y<l$ ), who live miserably off their fishing, and those who live inland, who are traders. The only 'Azenègues' who appear to resist them are those of the great mountain of Idjil: great in number (with two kings, 'Azenègues' like them), 'these are the main enemies of the Alarves, so much so that they dare not leave their mountain, just as the Alarves dare not enter it' (de Cenival and Monod 1938: 77).

Even if such an account has its limitations, it does display the variety of statuses and living styles across the various groups. In describing the superiority of the Arabs over most of the other groups, Fernandes aptly reflects the position of the descendants of the Banī Hassān in Moorish society. As for the status of the poor 'Aznègues', held to ransom by the 'Alarves', it corresponds closely to that of a tributary group. Curiously, they have become the only ones to bear the name àznāgä in Hassāniyya (uznägän in Zenāga). This does not prove that they continued speaking Zenāga longer than the others, but it does explain why one would hardly expect a free (and noble) man to claim Zenāga (or even Berber) ancestry. As for speakers of Zenāga (past or present) who have preserved their status of nobles, they have chosen a different name, or defined themselves differently: in Zenāga as ugudayän, as opposed to 'warriors' (äräbän); ${ }^{34}$ in CLA ${ }^{35}$ as Șanhāja, and in Hassāniyya as zwāyä 'scholars'. Rare indeed are warrior tribes or groups which are not reputed to be of Arab descent (the Idaw ${ }^{\mathrm{C}} \overline{\mathrm{i}} \mathrm{sh}$ are the exception that proves the rule). ${ }^{36}$ But this does not mean, inversely, that all zwāyä tribes are former Zenāga speakers, even if the descendants of the Almoravids have generally shown much more interest in Islamic literary culture than have the descendants of the Banì Hassān.

Independently of groupings into tribes ( $\left.q a b \bar{a}^{2} i l\right)$ and subtribes ( $\ddot{a} f x \bar{a} \underline{d}$ lit. 'thighs') where rank is the subject of continuous classification disputes (Ould Cheikh 1985), there are families which have a particular status. On the one hand there are the iggāwan, the traditional musicians-courtiers to the warriors, ${ }^{37}$ and on the other hand the $m^{\varsigma}$ allmin, who, in Hassāniyya, are master crafters, the women working in leather, the men metal and wood. These are tightly closed groups (among whom only iggāwan women are allowed to marry outside), and their statuses (and titles) tend to be identical in neighbouring societies. Thus the Hassāniyya term iggīw 'griot', either from Wolof (gēwel) or Pulaar (gawlo), was borrowed via Zenāga (īggiwi, $\mathrm{pl} \bar{a} g g \bar{u} n)$. This status has no equivalent in Tuareg society, ${ }^{38}$ contrary to that of

34 The term ugudayän has been likened to qādi 'judge', one of the main functions undertaken by the scholars (Taine-Cheikh 2008: 181). Souag (2010: 184) relates the term to tagadilt, which means 'owner (f)' in Tetserrét.

${ }^{35}$ It is very curious to note that the form 'Șanhäja' (first written and then in speech) has lost, in the Moorish consciousness, all connection with the spoken form 'Zenāga'.

36 According to Dubié 1940: 320 'The Moors have the custom of saying: "a Moor who speaks Zenāga is certainly not a Zenāgui (which is to say: a laḥma or tributary), nor a warrior”.... Anyone speaking Zenāga, formerly, was considered a fervent Muslim: the scholars had acquired moral and spiritual ascendancy over the Hassanes, the latter refraining from pillaging encampments where Zenāga was spoken.'

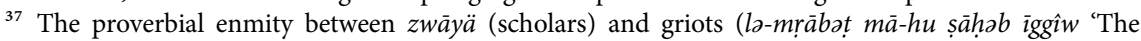
scholar is not the friend of the griot') can be considered a legacy of the religious condemnation pronounced against the latter by the Almoravids.

${ }_{38}$ The term aggu 'guitarist griot (a traditional guitar-playing bard)' has however been noted in Niger (Prasse et al. 2003: 193). 
blacksmith, which in Zenāga is called $\ddot{a} n m u^{2} \underline{d}$ (the emphasis on the final consonant reappearing in the f: tänmu $\underline{d} / t_{a ̈ n} m u^{2} d$ ) and in Tuareg éned or enäd (de Foucauld 1951-2: 1300; Prasse et al. 2003: 589). ${ }^{39}$

In these class-ridden societies, the distinction between men who are free and those who are not is very important, but the degree and form of subordination seems to have changed over time. Thus alongside the status of slave, ${ }^{40}$ one finds the hartāni (ähardan in Zenāga) which is, depending on the case and the location within the Sahara, either a 'freed slave' or a descendant of the original inhabitants of the oases. ${ }^{41}$

In the light of this brief overview of West Saharan society, ${ }^{42}$ one notes that, beyond the similarities with the social organization of the black sedentaries of the Valley, there is a high degree of terminological convergence between both Hassāniyya and Zenāga on one hand, and Zenāga and Tuareg on the other. This means that the main features of this society were already in place before the arrival of the Banī Hassān (Ould Cheikh 1995). However, their arrival certainly tended to make the differentiation between the people of the sword and those of the pen even sharper, especially in the south-west following the Shurr Buḅ̣ä war in the seventeenth century, which ended in defeat for those who were seemingly in favour of a governing power more in keeping with Islamic precepts. Above all, their impact was the Arabization of the region, the resulting language retaining, however, many lexical borrowings from local languages, especially Zenāga.

Despite the importance of trade with societies in the south, the imprint left on Hassāniyya by black African languages appears, to date, to have been extremely small. The fact that mbūru 'bread' and māru 'rice' come from Wolof (mburu and $m a \overline{l o}$ ) is of little significance in a society where until recently such foods were unknown. The same could be said for the origin of kaddu 'spoon' (from the Wolof $k u d d u$, WAD II: 314), especially as other forms are used with the same meaning.

Concerning terms of Pulaar origin, one may especially note: gärtä 'peanut', näyrwä(l) 'crocodile', ị̣umḅi 'large calabash', sīrä 'gum incision', and daba 'seedbox iron'. Several borrowings from this language have palatalized consonants, such as $t^{y}$ ì $b \ddot{a}$ 'central pillar of a dwelling', $t^{y}$ วhli 'hangar', $d^{y}$ owgal 'very thick stalk (of cereals)' and $d^{y} \ddot{a} k k \ddot{a}$ 'keep under restraint'.

Soninke, by contrast, has less of a presence, apart from the toponym Chinguetti (< si n-gede 'well of the horse'), a name which has (ironically!) become the emblem of Moorish society, and the Berberized name ädäbāy (< dèbé 'village', cf. Diagana 2011: 39) which denotes a 'freed' village of sedentary hṛātīn. This is without counting, however, the terms from Azer noted in Tichitt by Jacques-Meunié (1961), such as $k \bar{a}$

39 In Tetserrét, the term used is even closer to Zenāga: anəmməd 'craftsman, blacksmith' (Attayoub 2001: 91).

40 A further category must be distinguished, of 'tent' slaves: Hassāniyya nānm ${ }^{w} \ddot{a}<$ Zenāga $o^{2} b \underline{̣}$ äään nānmän lit. 'slaves [of] close kin'.

${ }^{41}$ One must note the distinction in gender whereby in Hassāniyya a female slave is termed $x \bar{a} d \partial m$ rather than the f of ' $a b d$, which is not in use. It means 'she who works, who serves', even though the verb from which $x \bar{a} d \partial m$ is derived is used only in one part of Mauritania (the north and east) (Taine-Cheikh 1988-98: 516).

42 In the main, it still holds today: the difficulties encountered by Mauritania in eradicating all traces of slavery are well known, as are the repeated declarations of abolition. 
'house' in kā n lak 'house entrance', killen 'inside alley', kunyu 'kitchen' (cf. ká, killé and kinyú in Diagana 2011: 96, 107).

Even putting to one side the Hassāniyya spoken in Mali, where Heath (2004) observes a number of borrowings from Songhai, these are only a few of the terms borrowed from the languages of the sedentaries in the south. Much remains to be done in this domain, in particular to trace the origins of some of the specialized vocabulary: in music, for example (Guignard 2005), and regarding the architecture of ancient cities.

As for lexical items of Zenāga origin (or more generally Berber, some terms such as gäymär 'to go long-distance hunting' go back to the pan-Berber form gmar which is not, or no longer, used in Zenāga), they are undoubtedly the largest element, even though, once again, the inventory is not yet complete. It has often been said that subject fields such as plants, date-growing, and cattle-raising have largely borrowed from Zenāga. That is true, but these are not the only fields, as shown by the study of the various semantic areas which are tightly linked to nomadic life, whether in terms of material culture, milk production and consumption, or specialized activities of various groups, such as hunting and fishing (Taine-Cheikh 2010, 2013b, 2014c). One also notes that Hassāniyya, the target language, can also be a source language and that this back-and-forth at times produces 'mixed' forms. This creates, on the margins, an impression of proximity between the two languages, without Hassāniyya or Zenāga losing the distinctiveness which makes the first a variety of Arabic, and the second a variety of Berber. Beyond this distinctiveness, however, there are many similarities, especially from a typological standpoint.

\subsubsection{CULTURAL AND LINGUISTIC UNIFICATION}

Although the overarching term Mauros used by Fernandes undoubtedly corresponded, at the beginning of the sixteenth century, only to a very partial unification of groups speaking Zenāga and Hassāniyya, five centuries on there has indeed been total integration of both communities within what has become Mauritania. Indeed, the last speakers of Zenāga all consider themselves members of the group of bì $\bar{d} \bar{n}$ (an ethnonym which denotes whiteness and which is generally translated as 'Moors'). The fact that this community defines itself first and foremost negatively, in contrast to the sūdān ('blacks'), is a feature shared by all nomadic groups in the Western Sahara and is the outcome of centuries of relationships, both cooperative and competitive, with the sedentary groups to the south and south-east.

The main factor in the recession of Zenāga was certainly the arrival of the Banī Hassān, but the existence of several empires in which other languages predominated may have hastened its extinction. This seems to have been especially the case in the east, where, from the eighth century, the empires of Ghana, Mali, and the Songhai successively ruled over the geographic area inhabited by the Zenāga.

In the south-west there have been other kingdoms but, in contrast to the eastern regions of Tichitt and Walāta, where the power of the empires appears to have been wielded forcefully, the western region of Trarza seems to have had more peaceful relations with the kingdom of Waalo. On the banks of the river Senegal one finds groups claiming the same ancestry (the famous sherif $b \bar{u}$-bäzzūl (lit. 'of the breast'), 
so called because he is said to have suckled his son in the absence of his mother), and that could be an indication of this closeness. Furthermore, the oral traditions of the Waalo depict Abū Bakr Ibn 'Umar, the chief of the southern branch of the Almoravids, as the ancestor of several branches of the royal dynasty of Waalo (Monteil 1964; Bonte 1998: 67). ${ }^{43}$

More concretely, the trade relations created by the trans-Saharan coastal route have contributed to giving the south-western region a special status in its relations with the tribes of southern Morocco. This involvement in a trade route distinct from those inland helps shed light on the split between areas using $\dot{g}$ and those using $\dot{g}>q$. It has also facilitated the preservation of the particularities of the south-western region, especially following the decline of the western branch of trans-Saharan trade, starting perhaps as early as the fifteenth century. Indeed Wolof in particular, which, in the twentieth century, has often been used in Mauritania as a lingua franca, was also used at an earlier period in the south-west for cross-community communication, and was therefore in a position to compete with Hassāniyya as a trade language.

In the absence of precise descriptions as to how and at what speed Hassāniyya was adopted following the arrival of the Banī Hassān, one can compare the situation of Zenāga speakers, as laid out in Dubié 1940, with the current situation (Ould Cheikh 2008). At the time of Dubié's study, Zenāga was being spoken by about 13,00o people only, and among the three tribes still speaking it, transmission to younger generations is assured only by the Idab Lahsen tribe, the tribe of our informant. The forecast death of Zenāga has thus moved closer, largely as a result of schooling and migration to the capital Nouakchott. Though there were particularly violent upheavals in the second half of the twentieth century, the language switch to Hassāniyya has happened very slowly, and depended on the closeness of the relationship with purely Hassāniyya-speaking groups and matrimonial alliances. ${ }^{44}$ It is noteworthy that the Idab Lahsen who, for historical reasons (stemming from the war of Shurr Buḅuä), married less outside their tribe and stayed further away from the Trarza Emir's encampment, are also the ones who have best preserved their language.

Dubié 1940: 319 gives another reason for this conservatism: the fact that the Idab Lahsen were all 'lesser roaming' nomads and that, among the two other groupings, the 'lesser roaming' tribes had preserved Zenāga better than the 'wider roaming' ones. If this fact did play a part, which is highly probable, it could also shed light on one of the factors which made possible the transmission of Hassāniyya. However, the mere fact of groups (and individuals) being brought into close contact and spending more

${ }^{43}$ Lastly, one may mention the case of the tribe of the Awlād Bän ${ }^{\mathrm{y}} \mathrm{n}^{\mathrm{y}} \mathrm{u} g$. This very southern branch of the Banī Hassān, whose territory is located at the mouth of the river Senegal, is known in effect for speaking Hassāniyya with traces of Wolof-an influence which could be explained by the fact that the members of this tribe are often Arabic-Wolof bilinguals.

${ }^{44}$ Marriage with non-Zenāga speakers certainly played an important role, especially in a patrilocal society (or one that became one long ago) such as that of the Moors. Studies on kinship in the Adrar tribes show how the matrimonial rule of female hypergamy (= not marrying a person of a lower social class) was manipulated to reinforce the political power of the Emir and tribal chiefs (Bonte 1987, 1998). Indirectly, they attest to the fact that more closed groups prefer marriage among first cousins, whereas political alliances favour marriage with women from further afield. 
or less lengthy periods of time together is not a sufficient explanation of why there is so little variation in Hassāniyya across time and space. Certainly, there were no religious conflicts liable to favour particular linguistic features, and one cannot say either that the ancient cities were composed of true sedentary populations, in contrast to the world of the nomads, because the cities were fully involved in transSaharan trade. As far as a central government is concerned, it began to appear in embryonic form only at the time of independence, in 1962. The emirates, the first of which (Trarza) dates back to the seventeenth century, do not seem to have shown any desire for explicit control over Hassāniyya, despite the indirect influence they certainly had in promoting the dialect.

In order for the unity of Hassāniyya to be preserved, there must have been, among Arab warriors, some sort of 'communal vision' capable of transcending the anarchistic and individualistic tendencies they are otherwise known for. This shared vision, which considered genealogy the sole point of reference, even if it was reconstructed, was fundamentally 'retrospective' and showed a tendency, in language as elsewhere, to glorify the past. This did not prevent Hassāniyya from evolving and introducing some innovations, but these are of a different type from those commonly observed among sedentary tribes. Indeed, Hassāniyya has on the whole remained a 'synthetic' type of language, showing none of the innovations typical of 'neo-Arabic', such as: loss of direct annexation to express the genitive, and for numerals followed by a count noun; use of preverbal particles before the p-stem (especially to distinguish the habitual from the present continuous, and the possible from the certain); use of a discontinuous negative; creation of a (new) indefinite; placing an adverb before an adjective to express comparison; the disappearance of specifically passive constructions. In all of these areas, on the contrary, Hassāniyya shows constructions close to what are found in OA/CLA.

From this perspective, it is also not impossible that the intimate knowledge the $z w \bar{a} y \ddot{a}$ groups had of the corpus of Islamic texts played a role. The fact that all the children of literate families (boys and girls alike) spent their childhoods memorizing the Qur’ān, with the brightest knowing it by heart before the age of twelve, must certainly have left traces, indirectly, on the dialect. Moreover, such speakers were highly normative in their use of CLA-a lahn ('solecism') was shameful (Miské 1970: 47). ${ }^{45}$ This prescriptive tendency certainly influenced how they spoke the dialect, notably in demonstrating that they were capable of speaking Hassāniyya correctly. Indeed, one must not forget that Hassāniyya was the language of the victors (the Arab warriors) and that a good bidani is a Moor who has mastered the dialect perfectly. ${ }^{46}$

45 This normative attitude is apparent especially in the controversy surrounding the CLA pronunciation of the $d \bar{a} d$ (Bouvat 1913).

46 Some nomadic groups of Peuls who had very close ties to the Moors were also known for the excellence of their Hassāniyya. A deliberate tendency to not respect the rules of grammar in speaking Hassāniyya appeared among black Africans only after the forced imposition of CLA in schools and the administration and, more generally, a policy of oppressing the blacks, culminating in the events of the 1990s (Dia 2007). 
Although different in nature from CLA, Hassāniyya was just as unlikely to escape prescriptive attitudes because, for centuries, it was the language in which poetry was composed. Such poetry was highly popular, and followed simpler metrics than CLA poetry (si $i^{c} r$, composed only by the educated), but nonetheless had to obey a set of complex rules, the most important being the number of syllables per hemistich, and their length (Taine-Cheikh 1985). Poetry appears to be particularly well developed among nomadic peoples (Sowayan 1985) and, on this point, the Banī Hassān, like the bì $\underline{d} \bar{a} n$ as a whole, doubtless merely perpetuated ancient traditions. One must, however, note that the synthetic style of Hassāniyya is especially well suited to poetic composition. Profuse lexical creation in the language could perhaps also in part be ascribed to this poetic bent. Be that as it may, this is certainly the case for the major panegyric poems (thäydin) composed by griots.

However, beyond purely lexical innovations, one also notes in Hassāniyya the frequent extension of the rules of derivation (Taine-Cheikh 1991b):

- to (re)form the passive of derived patterns (with the prefix $u$ - in the s-stem);

- to create diminutive and elative forms for entire series of lexemes (nouns, adjectives, and verbs for the former; adjectives and verbs for the latter).

These derivations are used in OA syntactic constructions of a synthetic type which have often disappeared from the dialects (especially among sedentary groups in the Maghreb). For this reason, and because derivations such as the diminutive are particularly productive in the dialects of nomads, these specific features can be considered characteristic of 'bedouin' dialects.

Within that framework, it is interesting to note that Zenāga and Hassāniyya have many points in common. Some are also points of divergence from the northern dialects, such as absence of discontinuous negation and of a preverbal particle before the p-stem. Others appear rather to be innovations parallel to forms in Hassāniyya. This is especially the case with:

— yänhäyä 'be preoccupied (by)', used in Zenāga to express the future, whereas in Hassāniyya one uses $l a \bar{h} i$, a participial form with nearly identical meaning;

- diminutive forms which, in the masculine singular, combine the feminine suffix - $t$ and the prefix $a \dot{g}-$, such that Zenāga, at least for nouns, has equivalents for Hassāniyya diminutives. ${ }^{47}$

The inventory of similarities between Zenāga and Hassāniyya shows that they are numerous, including some in phonetics and phonology, but Zenāga cannot explain the peculiarities of $/ f /$ in Hassāniyya (pronounced voiced except in Mali) nor those of $/ \dot{g} /$ (except perhaps for the geminate $\dot{g} \dot{g}>q q) .{ }^{48}$ In contrast, causative derivation in Zenāga, even though it is marked more often by the prefix $\check{s} a$ - than by the prefix $s a$ - (or $z a$ - or șa-), certainly influenced the formation of the new causative derivation: one also finds in Hassāniyya forms in sä- such as säntä 'begin' and sädbä 'make

\footnotetext{
47 This novel formation, found in the toponym Awdaghust (lit. 'people of the small west') and in many other toponyms as far afield as the Walāta region, was also noted in Tetserrét by Attayoub (2001).

${ }^{48}$ In Zenāga, $\dot{g}$ > ?
} 
(s'one) leave in the afternoon' which clearly are from Zenāga roots (Taine-Cheikh 2003). This is one of the traits in Hassanniyya whose origin is hotly disputed, but there are a few others in the morphosyntactic domain (Taine-Cheikh 2008b).

At the close of this attempt at a historical reconstruction, it seems that although classification by dialectal features is often difficult (because of, among other reasons, the 'multivalence' of dialect features (Ingham 1982: 31), the typological dichotomy between 'bedouin' dialects and 'sedentary' dialects retains its full explanatory power. It is probable however that, in order to keep its characteristics, the 'bedouin' dialect type must have been transmitted without any disruption and without 'corruption' from outside influences (Versteegh 2011: 544). In the case of Hassāniyya, this is indeed what happened. 'Corruption' could have come from contact with Zenāga if this language variety had not also been a language of the 'bedouin' type. There was thus a radical language shift, but it did not affect the unity, the synthetic nature, or the noninnovatory character (except in derivation) of the 'glottophagic' Arabic language. ${ }^{49}$

49 On the notion of 'glottophagic language', see Calvet 1974. 